\title{
Wild bees along an urban gradient: winners and losers
}

\author{
Weronika Banaszak-Cibicka $\cdot$ Michał Żmihorski
}

Received: 27 September 2010/ Accepted: 7 July 2011/Published online: 22 July 2011

(C) The Author(s) 2011. This article is published with open access at Springerlink.com

\begin{abstract}
The variability of bee communities along an urban gradient has a potentially strong impact on pollinator-plant interactions. We investigated changes in bee species richness and community composition in the city centre and suburbs of Poznań, Poland. During 2006-2008 we recorded 2,495 individuals from 104 species. The most abundant species was Andrena haemmorhoa. Other abundant species were Bombus pascuorum, Andrena vaga, Andrena nitida, Bombus terrestris. Several species appeared to be more abundant in the city centre whereas others showed an opposite tendency. We have found that the urbanized landscape can act as a filter for the bee community since some specific ecological traits facilitate colonization of the city centre. Small-bodied species that start their activity later in the season and are not solitary preferred the city centre. However, bee species diversity and richness remained stable across the urban gradient indicating some advantages of being a city dwelling bee. We suggest that a city can be a very important habitat for a diverse bee fauna and that conservation of a wide range of habitats of different urbanization levels seems to be the most suitable strategy for conservation of bee diversity in cities.
\end{abstract}

Keywords Hymenoptera · Apoidea · Bees ·

Urbanization · City · Poznań

W. Banaszak-Cibicka ( $\square)$

Institute of Zoology, Poznań University of Life Sciences,

Wojska Polskiego 71C, 60-625 Poznan, Poland

e-mail: banaszak@up.poznan.pl

M. Żmihorski

Polish Academy of Sciences, Museum and Institute of Zoology,

Wilcza 64, 00-679 Warsaw, Poland

\section{Introduction}

In recent years, interest in the urban bee fauna has increased (McIntyre and Hostetler 2001; Frankie et al. 2005; McFrederick and Le Buhn 2006; Fetridge et al. 2008; Matteson et al. 2008; Wojcik et al. 2008; Pawelek et al. 2009). Urbanization causes a drastic and persistent change in the landscape and environment which, in turn, transforms interspecific interactions within communities (McKinney 2006). Replacement of natural habitats by human-dominated areas results in habitat loss and fragmentation. The isolation of a habitat patch may also affect the abundance and diversity of insect species. Habitat fragments isolated in human-dominated regions are less likely to be colonized by the native biota (Kozlov 1996; Van Dyck and Matthysen 1999). Fragmentation and destruction of semi-natural habitats and replacement with exotic plants may also be the cause of the changes of insect populations. For example an exotic rich winter foraging resource in urban parks and gardens give a possibility of changes in pollinator phenology (Stelzer et al. 2010). Moreover plant species richness often increases in urban areas compared to more natural areas (Grimm et al. 2008).

Many species will have to survive in human-modified areas if they are to survive at all and anthropogenic habitats offer more opportunities for conservation than was previously thought (Gascon et al. 1999). Moreover, focussing public attention on city-dwelling species provides greater opportunities for researchers to demonstrate the importance of conservation to society. It is clear that the perception of wildlife by society is crucial for effective conservation of biodiversity (e.g. Clucas et al. 2008; Home et al. 2009; Mulder et al. 2009). Therefore, in light of these facts, knowledge on wildlife in urban areas seems to be of high importance for biodiversity conservation in heavily modified areas. 
Bees play a very important role in plant pollination, both in the natural environment and in human-dominated habitats. They also act as hosts and prey for other species. Therefore, the response of bee communities to urbanization seems to be crucial for the maintenance of biodiversity within cities. For bees, urbanization means a change in the availability of nesting sites as well as the quality and accessibility of food plants. It can also affect bees through habitat fragmentation (McIntyre and Hostetler 2001; Cane 2005a; Frankie et al. 2005; Ahrné et al. 2009). Urban environments are mosaics of habitats that are regularly disturbed and communities need to be dynamic to adapt to disturbances imposed by human activities (Sattler et al. 2010). However, little is still known about the effects of urbanization on the richness and composition of bee communities (Cane 2005a; Hernandez et al. 2009). Moreover, further research needs to be made on trait variation in relation to urbanization. There may be some species-specific traits which facilitate existence in a urban environments and urbanization may affect different species differently (Bańkowska 1980, 1981; Niemelä et al. 2000; McIntyre et al. 2001). Urbanization tends to alter species composition from that of the surrounding landscape (Grimm et al. 2008; Matteson et al. 2008; Kadlec et al. 2009).

The aims of our study were (1) to identify the bee species present within the city centre of Poznań, Poland; (2) describe the response of different bee species to increasing urbanization and (3) to find species-specific traits which facilitate existence in an urban environment. We put forward a hypothesis stating that bee species diversity decreases as urbanization increases and that city centre bees differ in terms of their ecological traits from suburban-dwelling bees. Moreover, we expect that some of species-specific traits (e.g. foraging or nesting behavior) can be helpful in selecting winners and losers among bee species that inhabit urbanized landscapes.

\section{Materials and methods}

\section{Study area}

The study was carried out in Poznan $\left(52^{\circ} 25^{\prime} \mathrm{N}, 16^{\circ} 58^{\prime} \mathrm{E}\right)$, a city with 560,000 residents, over 3 years (2006-2008). Bees were sampled on eight sites $(50 \times 50 \mathrm{~m})$ located within the urban matrix representing a wide spectrum of urban environments (Fig. 1). For this purpose we selected large green areas, potentially available for many bee species with the aim of identifying the full set of species present in the city. We were not able to include all the green areas in the city but included the largest ones which are probably the most important for the studied group. The plots (Fig. 1) were along an urbanization gradient and comprised: Plot 1-The garden behind the church surrounded by concentrated settlement of tenement houses (CS1); Plot 2-The garden in front of The Museum of Utilitary Art in the Royal Castle surrounded by concentrated settlement of tenement houses (CS2); Plot 3-Green area between concentrated settlement of tenement houses (CS3); Plot 4-River meadow close to concentrated settlements (RV); Plot 5-Botanical Garden (BG); Plot 6Dendrological Garden (DG); Plot 7-Green area in a sparse housing estate (HE); Plot 8-Home garden located in a district of detached houses (HG).

On the basis of the percentage of built up areas within a $500 \mathrm{~m}$ radius from the sites, percentage of tree cover within $500 \mathrm{~m}$ radius, percentage of green areas cover (including tree cover) within $500 \mathrm{~m}$ radius and distance from the city centre we divided the eight plots into city centre $(n=4)$ and suburb $(n=4)$ classes. As the variables were correlated we used principal component analysis (PCA) to combine the four variables into one component explaining $89 \%$ of variance of original variables. Positive values of the component (hereafter referred to as "urbanization") represent urbanized habitat whereas negative values represent suburban habitats. For some of the analyses all the plots were divided on the basis of the "urbanization" component into urban (Plots no. 1-4 in Table 1) and suburban (5-8) plots.

\section{Bee sampling}

Yellow Möericke traps were used to catch the specimens as they had previously been used successfully for the collection of bees in urban fragments (Banaszak 2004). Within each site four yellow pan traps were used. Insects were collected from traps every 7-10 days from April to September for 3 years (2006-2008). The collected specimens were temporarily stored in $70 \%$ ethanol until pinned for identification. Direct searching along transects, which covered the most attractive resource patches, was also conducted at each site. On transects, bees were netted by hand twice each month from April to September. Within the plot the surveyor walked at a slow speed among any potentially attractive resource patches and collected bees during an observational period of $30 \mathrm{~min}$. Species that could not be identified in the field were kept for identification later. In total, 187 samples were collected over 3 years (from 14 to 44 samples per plot).

All individual bees were pinned in the laboratory, sorted and identified to species. Ecological traits for each species were compiled from primary literature, catalogs, and reference works (Banaszak 1993; Scheuchl 1995; SchmidEgger and Scheuchl 1997; Banaszak et al. 2001; Pesenko et al. 2002; Pawlikowski and Celary 2003). For each 
Fig. 1 Location of study plots in Poznań (City centre: CS1, CS2, CS3 concentrated settlements of tenement houses, $R V$ river meadow close to concentrated settlements; Suburbs: $H G$ Home garden located in a district of detached houses, $H E$ sparse housing estate, $D G$ Dendrological Garden, $B G$ Botanical Garden)

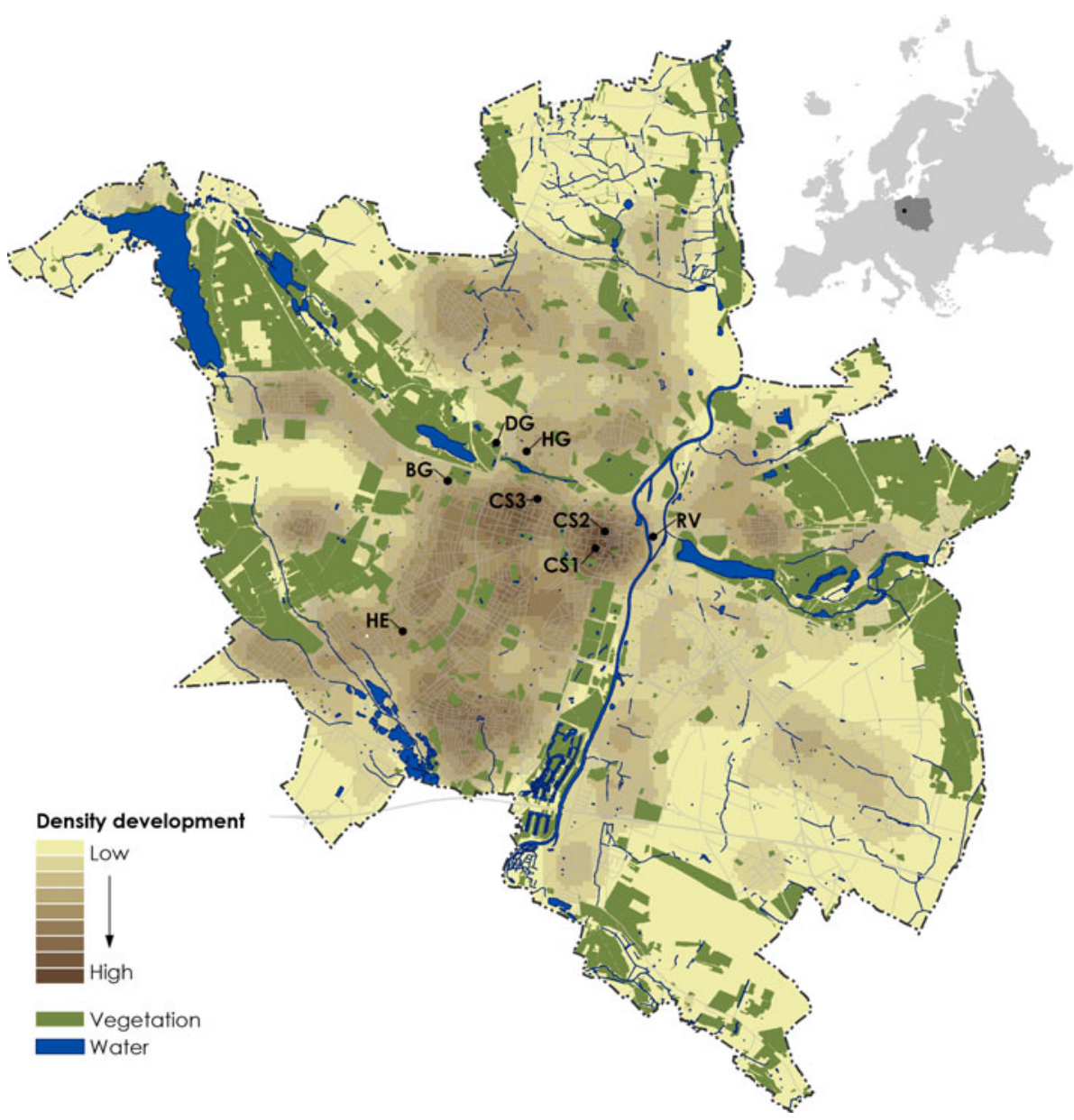

Table 1 Characteristics of the eight plots and values of the component "urbanization" extracted by PCA

\begin{tabular}{lllllll}
\hline No. & Plot & $\begin{array}{l}\text { \% Built up } \\
\text { areas } \\
r=500 \mathrm{~m}\end{array}$ & $\begin{array}{l}\% \text { trees, } \\
r=500\end{array}$ & $\begin{array}{l}\% \text { green, } \\
r=500\end{array}$ & $\begin{array}{l}\text { Distance to centre } \\
(\mathrm{m})\end{array}$ & $\begin{array}{l}\text { Component } \\
\text { "urbanization" }\end{array}$ \\
\hline 1 & $\mathrm{CS} 1$ & 80 & 5 & 10 & 250 & 1.190 \\
2 & $\mathrm{CS} 2$ & 90 & 5 & 10 & 700 & 1.217 \\
3 & $\mathrm{CS} 3$ & 70 & 10 & 20 & 1,800 & 0.640 \\
4 & RV & 50 & 5 & 35 & 1,050 & 0.487 \\
5 & BG & 30 & 25 & 50 & 2,730 & -0.533 \\
6 & DG & 40 & 20 & 50 & 4,900 & -0.672 \\
7 & HE & 20 & 40 & 65 & 3,420 & -1.206 \\
8 & HG & 15 & 30 & 70 & 3,480 & -1.124 \\
\hline
\end{tabular}

species richness of bees (Gotelli and Colwell 2001). We species mean body length, nesting place (cavity or soil), social behavior (solitary, eusocial or parasitic), floral specificity [e.g. oligolectic (single plant species or genus), polylectic (many plant species)], phenology—month of first activity (e.g. April, June, July) was determined.

\section{Statistical analysis}

We used rarefaction curves implemented in EstimateS 800 software (Colwell 2005) to analyze species diversity and used the MaoTau estimator as a function of the number of individuals included in the analysis (individual-based rarefaction curve) from the two localities (centre vs. suburbs). The estimator generates the expected number of species for a given number of sampled individuals in the two classes (Colwell 2005). We used individual-based rarefaction since it is independent of possible differences in mean number of individuals per sample between the classes (Gotelli and Colwell 2001). Next, we made an 
attempt to estimate total species richness of the bee community in the two classes. For this purpose we estimated the number of unseen species (i.e. missed during sampling) with the help of abundance-based coverage estimator (ACE). The ACE approach uses abundances of rare species to estimate number of all species in a given class (Chao et al. 2006).

We used an unconstrained ordination method: detrended correspondence analysis (DCA) implemented in CANOCO 4.5 for gradient length diagnostics, and canonical correspondence analysis (CCA) for comparison of bee communities with ecological traits (Lepš and Šmilauer 2003). For the set of 187 samples we used distance to the city centre and \% built-up areas in the vicinity (radius $=200 \mathrm{~m}$ ) of sites as two explanatory variables in CCA. The day of the season $(1=1$ st March $)$ of each sample was used as a third explanatory variable in order to control temporal variability within the community. Moreover, we used year as covariables to exclude possible between-year variations in the community. Species data were log-transformed prior to analysis. A Monte-Carlo test with 5,000 permutations was used to test the significance of the canonical axes. We restricted the number of bee species presented on the CCA biplot to 62 species for which the three explanatory variables (mentioned above) explained at least $1 \%$ of their variability in the sites. Finally, general additive models (GAM) were used as a visualization method to show the variability of species richness, abundance and Shannon diversity index among sites along the two first axes of the CCA (Lepš and Šmilauer 2003).

We made an attempt to investigate species-specific traits explaining their preference for or avoidance of urbanization. For this purpose we divided all the bees into two categories: centre-dwelling (more abundant in the centre compared to the suburbs) and suburb-dwelling (reverse pattern). Available ecological traits for all the species $(n=104)$ were used to explain species-specific preferences or avoidance of urbanization with the help of a generalized linear model (GLM) with binomial error distribution and logit link function (Quinn and Keough 2002) implemented in SPSS 16.0. As explanatory variables we used mean body length (covariate), social characteristic (factor) and month of first activity during the year (covariate). Akaike information criterion (AIC) was used to select the most parsimonious model from the set of competing models (Johnson and Omland 2004).

Finally, we compared the bee fauna recorded in Poznan with the non-urban bee community reported from Wielkopolski National Park, located in the vicinity of Poznań. For this purpose we used detrended correspondence analysis (DCA) in CANOCO (Lepš and Šmilauer 2003).

\section{Results}

Species composition

We collected a total of 2,495 individuals from 104 species (Banaszak-Cibicka 2009); the Chao1 species richness estimator, corrected for unseen species in the samples, suggested 124 species. All of the collected species were native species. The most abundant species (accounting for $11 \%$ of all individuals collected) was Andrena haemmorhoa (Fabricius, 1781). Other abundant species were Bombus pascuorum (Scopoli, 1763), Andrena vaga (Panzer, 1799), Andrena nitida (Müller, 1776), Apis mellifera (Linnaeus, 1758), Bombus terrestris (Linnaeus, 1758); these five species accounted for $29 \%$ of individuals collected. These species are eusocial bees (Bombus pascuorum, Apis mellifera, Bombus terrestris) or early spring solitary bees (Andrena haemmorhoa, Andrena vaga, Andrena nitida). Twenty-two species were represented by only a single individual. The most represented families were Andrenidae (26\% of species, $38 \%$ of individuals), Halictidae (22\% of species, $18 \%$ of individuals) and Apidae (12\% of species, $28 \%$ of individuals).

Most bees were soil nesting (57\% of species, $62 \%$ of individuals), polylectic ( $74 \%$ of species, $88 \%$ of individuals) and solitary (65\% of species, $56 \%$ of individuals). Parasitic species made up a small proportion of the urban bee community ( $12 \%$ of species, but only $0.9 \%$ of individuals). Oligolectic species, which collect pollen from within a single family or genus of plants, were also rare ( $15 \%$ of species, $10 \%$ of individuals). The ecological traits of the recorded species are given in the Table 4 (Appendix).

\section{Diversity and species richness}

The expected cumulative number of bee species as a function of the number of sampled individuals was similar between city centre and suburbs (Fig. 2). For 600 sampled individuals the expected cumulative number of species was ca 66 for both urban classes. Estimated species richness, corrected for species unseen in the samples, was also similar between the two urban classes (Fig. 2).

Winners and losers on the urban gradient

Bee species showed very different responses to urbanization (Fig. 3). Some were recorded predominantly in the city centre [e.g. Hylaeus hyalinatus (Smith, 1842); Hylaeus angustatus (Schenck, 1859); Evylaeus nitidulus (Fabricius, 1804); Megachile pilidens (Alfken, 1923); Megachile rotundata (Fabricius, 1784)] while others showed the opposite pattern [Evylaeus lucidulus (Schenck, 1861); 


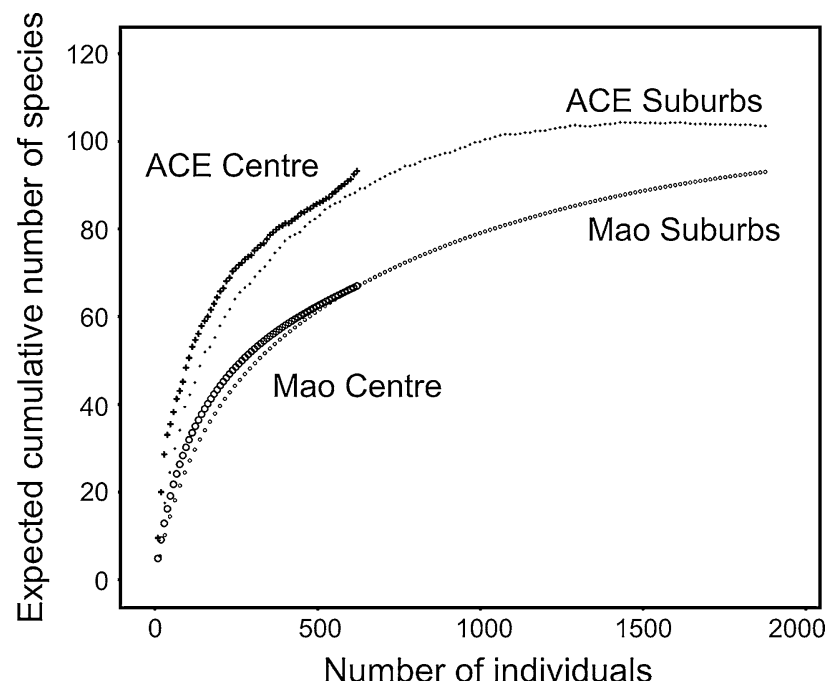

Fig. 2 Expected cumulative number of bee species (expressed with Mao Tau estimator) as a function of number of sampled individuals in the centre and suburb zones of Poznan, Central Poland. The abundance-based coverage estimator (ACE), corrected for species unseen in the samples is given for each habitat

Evylaeus calceatus (Scopoli, 1763); Panurgus calcaratus (Scopoli, 1763)]. The distribution and abundance of some species seemed to be unaffected by the urbanization gradient [e.g. Seladonia subaurata (Rossi, 1792)]. The distribution of species included in the analysis along the two canonical axes was not random (Monte Carlo test of significance of all canonical axes, trace $=1.025$, $F$ ratio $=2.80, P=0.0002,5,000$ permutations). The abundance of bees at sites decreased towards the city centre and a similar tendency, although less distinct, was recorded for the number of species per site (Fig. 3). However, species diversity found in particular samples, expressed by the Shannon index, did not show clear variability along the urbanization gradient (Fig. 3).

Ecological traits of winners and losers on the urban gradient

Species-specific ecological characteristics were usually associated. Social behavior was associated with nesting place (Chi-square test, $\chi^{2}=126.6 ; d f=6 ; P<0.0001$ ) and with floral specificity $\left(\chi^{2}=110.9 ; \quad d f=4 ; \quad P<\right.$ 0.0001 ). Therefore, only three of them (mean body length, social behavior and month of first activity) were used in modeling. Ecological traits included in the modelling significantly explained species-specific response to urbanization. The full model, containing social pattern, body length and time of first activity was the most parsimonious among the set of seven competing models (Table 2). The model was highly statistically significant.
The probability that a given bee species was more abundant in the city centre compared to the suburbs depended positively on its phenology: species that start their activity late (e.g. June-July) were significantly more associated with the city centre then species that start activity earlier (Table 3; Fig. 4). Solitary-living bees were significantly associated with the suburbs compared to species belonging to the two remaining social categories (eusocial bees and parasites). Mean body length, despite being non-significant (Table 3) was included in the most parsimonious model and, according to AIC, contributed to explaining species-specific responses to urbanization in 104 bee species.

Urban versus non-urban bee fauna

Bee communities recorded in the botanical and dendrological gardens in Poznań city were the most similar to the community reported from Wielkopolski National Park (WNP, Cierzniak 2003) whereas communities from the plots CS1 and CS2 were the less similar from that reported in the natural habitat. In general, distance along the first axis of DCA between the bee fauna from the Centre and WNP was smaller than the distance between the bee fauna from Suburbs and WNP (Fig. 5).

\section{Discussion}

General description of species composition in relation to previous research

The 104 bee species observed in Poznań during the study comprised $40 \%$ of the 259 species recorded from the region (the Wielkopolska-Kujavian Lowland, Banaszak 1982). The total number of bee species recorded to date in Poznan (Banaszak 1973, 1976, 1982; Wójtowski and Szymaś 1973a, b; Wójtowski and Feliszek 1977) is 184, i.e. $71 \%$ of the species recorded from the region. These data indicate that a city can be an important habitat for a diverse bee fauna.

The dominant species, Andrena haemorrhoa, Andrena vaga, Andrena nitida, Andrena fulva, Andrena ventralis, Osmia rufa and Anthophora plumipes, are early spring species which appear at the end of April and in May. The dominants from the Evylaeus and Bombus genus are eusocial species and Apis mellifera, accounted for 5.4\% of the collected individuals.

We also found some southern species which are rare in Poland: Megachile pilidens, Andrena florea, Andrena mitis and Osmia mustelina. These have not been recorded from the Wielkopolski National Park (situated $15 \mathrm{~km}$ south of Poznań) or from the Wielkopolska-Kujavian Lowland 


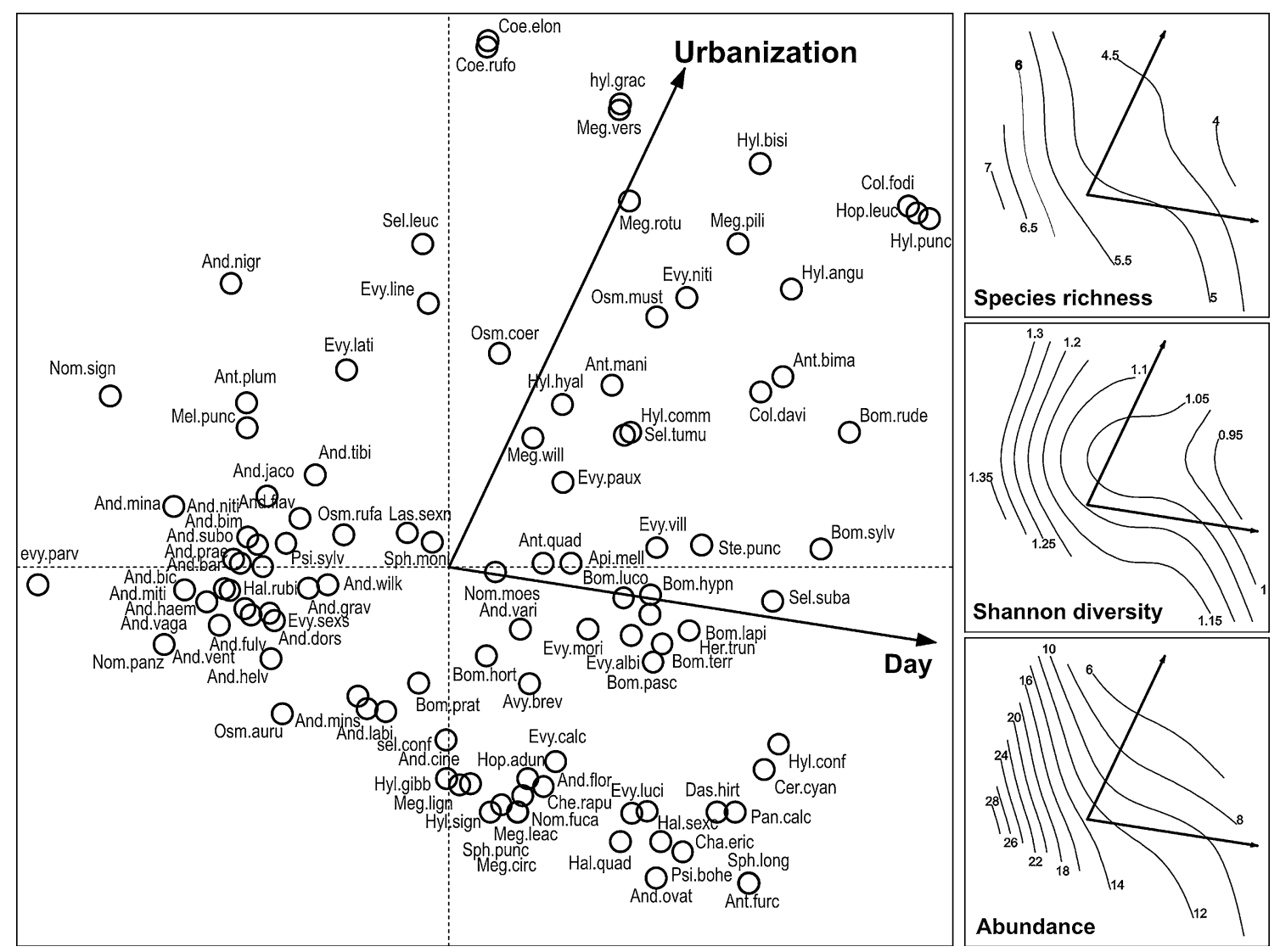

Fig. 3 Canonical correspondence analysis (CCA) biplot showing distribution of 62 bee species in relation to the urbanization gradient (expressed with component extracted from PCA-see "Methods" for details) and time used as explanatory variables along the two first canonical axis (large subplot). Abbreviations of species names use the first three letters of genus and the first four letters of species scientific names. Variability of the three diversity indices characterizing the bee community (species richness, abundance and Shannon diversity index) in relation to the habitat characteristics is shown with isolines fitted with a General Additive Model (smaller subplots)

Table 2 Akaike information criterion (AIC) scores of the eight competing generalized linear models with binomial error distribution and logit link function explaining preference or avoidance of 104 bee species to urbanization

\begin{tabular}{|c|c|c|c|c|c|c|}
\hline No. & Model & $k$ & AIC & $\Delta \mathrm{AIC}$ & $\chi^{2}$ & $P$ \\
\hline 1 & Soc. + length + phenol. & 3 & 99.064 & 0 & 25.65 & $<0.0001$ \\
\hline 2 & Soc. + phenol. & 2 & 99.366 & 0.302 & 23.35 & $<0.0001$ \\
\hline 3 & Phenol. & 1 & 102.057 & 2.993 & 16.66 & $<0.0001$ \\
\hline 4 & Soc. & 1 & 119.630 & 20.566 & 1.09 & 0.581 \\
\hline 5 & Length & 1 & 114.311 & 15.247 & 4.41 & 0.036 \\
\hline 6 & Soc. + length & 2 & 117.126 & 18.062 & 5.59 & 0.133 \\
\hline 7 & Length + phenol. & 2 & 101.503 & 2.439 & 19.21 & $<0.0001$ \\
\hline 8 & Intercept only & 0 & 116.503 & 17.439 & & \\
\hline
\end{tabular}

For each model number of predictors $(k)$, value of Akaike Information Criterion (AIC), value of AIC in relation to best model ( $\Delta$ AIC), test statistic $\left(\chi^{2}\right)$, and its significance $(P)$ are given. Soc. social behavior, length mean body length, phenol. phenology, month of first activity

except for Megachile pilidens which was found on xeric grasslands in the valley of the River Vistula. It is possible that urban areas which are warmer than surrounding countryside may provide better living conditions for these bees.

\section{Ecological characteristics of species found in Poznań}

The majority of bee individuals (62\%) collected in Poznan nest in the soil and the diversity and abundance of cavitynesting species was relatively low (9\% of individuals). In 
Table 3 Parameter estimates of a generalized linear model with binomial error distribution and logit link function, assessed as most parsimonious according to AIC (see Table 2 for details) explaining preference or avoidance by 104 bee species of urbanization

\begin{tabular}{|c|c|c|c|c|c|c|}
\hline \multirow{2}{*}{$\frac{\text { Effect }}{\text { Intercept }}$} & \multirow{2}{*}{$\frac{B}{-6.851}$} & \multirow{2}{*}{$\frac{\text { Wald }}{10.538}$} & \multirow{2}{*}{$\frac{P}{0.001}$} & \multirow{2}{*}{$\frac{\mathrm{OR}}{0.001}$} & \multicolumn{2}{|c|}{$95 \% \mathrm{CI}$ for OR } \\
\hline & & & & & 0.00002 & 0.066 \\
\hline $\begin{array}{l}\text { Social } \\
\text { behavior: } \\
\text { parasites }\end{array}$ & -0.191 & 0.039 & 0.844 & 0.826 & 0.122 & 5.581 \\
\hline $\begin{array}{l}\text { Social } \\
\text { behavior: } \\
\text { eusocial }\end{array}$ & 1.762 & 5.568 & 0.018 & 5.822 & 1.348 & 25.146 \\
\hline $\begin{array}{l}\text { Social } \\
\text { behavior: } \\
\text { solitary }\end{array}$ & 0 & & & 1 & & \\
\hline $\begin{array}{l}\text { Mean body } \\
\text { length }\end{array}$ & -0.124 & 2.197 & 0.138 & 0.883 & 0.749 & 1.041 \\
\hline $\begin{array}{l}\text { Month of first } \\
\text { activity }\end{array}$ & 1.298 & 14.205 & 0.000 & 3.661 & 1.864 & 7.189 \\
\hline
\end{tabular}

The table presents $B$ coefficient, Wald statistic and its significance, odds ratio (OR) and its $95 \%$ confidence intervals. The reference category for the parameter estimates is 0 (i.e. avoidance of city centre)

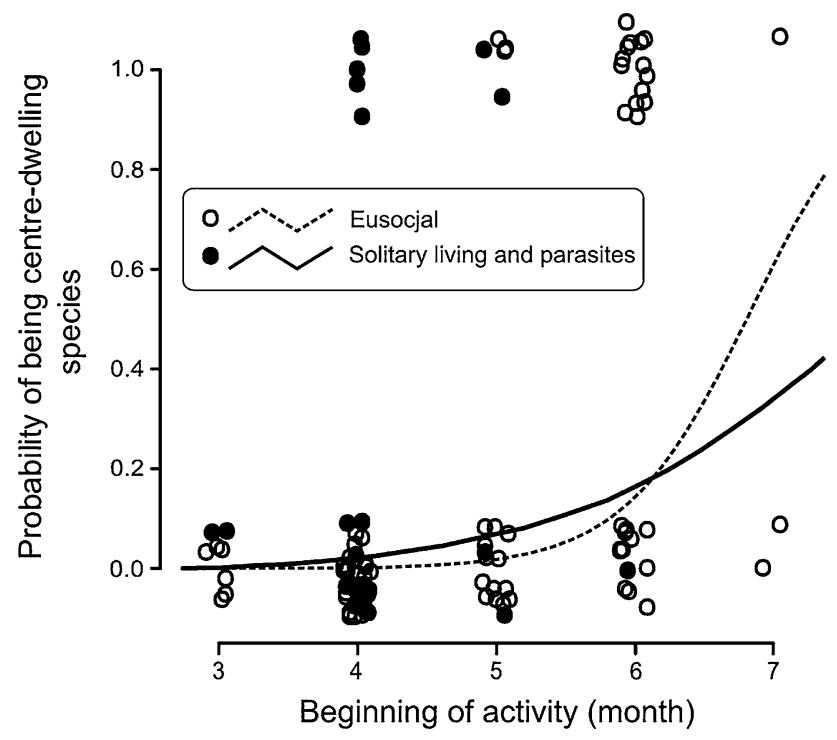

Fig. 4 The effect of species-specific social characteristics and month of first activity on the preferences of species to the city centre as assessed by logistic regression. Jittering was added to aid visualization. Note that fits are not adjusted for the body length effect that was included in the most parsimonious model on the basis of AIC

contrast, soil-nesting species and individuals in New York city gardens were relatively scarce (Matteson et al. 2008). A higher abundance of cavity-nesting bee species in urban areas has been shown in other papers (Cane 2005a; Zanette et al. 2005; Cane et al. 2006; Hinners 2008; Matteson et al. 2008). In our study, bee species from the family Andrenidae were the most abundant. Species of this genera are

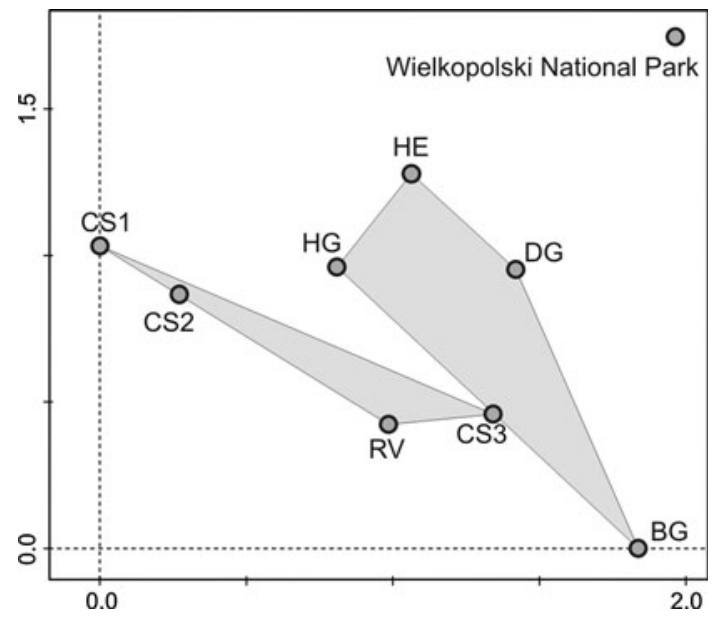

Fig. 5 Position of eight samples from Poznań city and sample from Wielkopolski National Park along the first two axes of detrended correspondence analysis (DCA)

largely ground-nesters and early spring fliers. In contrast to our study in many works that reported diversity of bee families, species from Andrenidae were rare in urban habitat patches (Owen 1991; Antonini and Martins 2003; Matteson et al. 2008; Wojcik et al. 2008). Scarcity of Andrenidae likely reflects a lack of appropriate flowering plants, especially trees, in early spring (Matteson et al. 2008). We suppose that the lack (or low number) of available food resources is the most important driver of low number of Andrenidae recorded in New York by Matteson et al. (2008). Our sites included the Botanical and Dendrological gardens where there were appropriate floral resources for these bees. However, the abundance of bee species from the family Andrenidae decreased with increasing urbanization (decreased percentage of tree cover in city centre). The relatively high abundance of Andrenidae also caused the proportion of soil-nesting species to be high in Poznan, as compared to other cities.

Cleptoparasites made up $12.5 \%$ of the collected species but only $0.9 \%$ of individuals. In residential urban areas in Berkeley, California, Frankie et al. (2005) found only 7.9\% of species to be cleptoparasites and in New York City urban gardens, parasites made up 5.6\% of collected species (Matteson et al. 2008). Cane (2005a, b) noted that cleptoparasitic species are largely absent in urban bee faunas and suggested that such species may require large host populations to persist. Despite the abundance of Andrena hosts collected in Poznań there were few cleptoparasites of the genus Nomada (four species, seven individuals).

Species traits promoting colonization of urbanized habitat

In agreement with our hypothesis, species found in the city centre and suburbs differed to some extent in their 
ecological traits. The probability that a given bee species was more abundant in the city centre compared to the suburbs depended positively on its activity pattern during the year: species that start their activity late (e.g. JuneJuly) more often preferred the city centre than species that start activity earlier. Low numbers of solitary-living early spring bees in the city centre are likely due to a lack of appropriate floral resources during the flight times of these bees. These species prefer trees as their main floral resource and in Poznań, trees are more abundant in parks and gardens and bigger housing estates outside the city centre.

Solitary-living bees preferred the city centre less than to social species. Previous authors have show that social species are more abundant in urban areas (e.g. Banaszak et al. 1978), probably because sociality permits behavioural and ecological flexibility. Additionally, social insects are considered to be species rich and ecologically dominant (Chapman and Bourke 2001).

Mean body length, while non-significant (Table 2) was included in the most parsimonious model and, according to AIC, contributed to explaining species specific responses to urbanization in 104 bee species. Small species were more abundant in the city centre. This may be related to habitat and food resource availability along the urbanization gradient. In general, green areas are smaller in Poznań city centre compared to the suburbs which may promote the smaller bees in such habitats. However, the importance of this trait seems to be rather weakly supported by the data and needs to be verified in future.

The floral diversity of urban habitats, such as small parks and gardens is often dominated by exotic and horticultural varieties (Thompson et al. 2003; Frankie et al. 2005; Gaston et al. 2005). Therefore, there is an expectation that generalist (polylectic) bee species may increasingly dominate urban locations. Generalist bee species with broad tolerances are favoured in urban areas (Cane 2005b; Eremeeva and Sushchev 2005) and many urban bee surveys indicate that floral specialists are scarce in urban habitats (Cane 2005a; Frankie et al. 2005; Cane et al. 2006; McFrederick and Le Buhn 2006). The most abundant oligolectic species was Andrena vaga which collects pollen from willow (Salix spp.) that grow in parks and gardens. However, the association between floral specificity and response to urbanization needs further study.

Advantages and disadvantages of being a city dwelling bee

The abundance of bees appeared to decrease towards the city centre. However, species diversity did not show a clear trend along the urban gradient. Therefore, we did not confirm the hypothesis of bee species diversity decreasing as urbanization increases. It has been shown that the increase of buildings associated with urbanization and the loss of vegetation cover have a negative effect on the abundance of bees (Zanette et al. 2005). On the other hand, urban areas also include flower rich green areas that can provide forage for a high diversity of wild bees (Frankie et al. 2005; Gaston et al. 2005; Loram et al. 2007). Cities may also contain materials and sites for nesting, such as bare soil, dead stems and cavities in man-made structures (McFrederick and Le Buhn 2006; Ahrné et al. 2009). Furthermore, urban areas have extremely high spatial habitat heterogeneity produced by many different land uses and plant cultivation at small spatial scales (Thompson et al. 2003) especially compared to the simplified and homogenous structure of the modern agriculture landscape. The mosaic of land use patterns may increase species diversity by increasing habitat diversity (Zerbe et al. 2003). This spatial heterogeneity can support even greater species richness than surrounding natural areas (Cierzniak 2003).

Most studies have compared urban, suburban or remnant habitat patches to natural areas and most of them documented lower species richness and abundance in urban areas than natural ones (McIntyre and Hostetler 2001; Fetridge et al. 2008; Matteson et al. 2008). However, in some groups of bees, such as bumble bees, species richness increased in urban areas relative to the surrounding natural habitat (Goulson et al. 2002; McFrederick and Le Buhn 2006; Winfree et al. 2007; Matteson and Langellotto 2009). There are few studies that have surveyed different site types within a city matrix along an urbanization gradient. Ahrné (2008) reported lower species richness of bumble bees and cavity nesting bees in areas containing a higher percentage of impervious surfaces. Her study concluded that urbanization is negatively correlated with bee species richness. In contrast, a study in Boulder County, Colorado showed that neither the number of species nor their abundance differed significantly among different levels of urbanization (Kearns and Oliveras 2009). The specific impact of urbanization on species richness will vary, depending on many geographical, historical and economic factors that are unique to each city (McKinney 2008).

\section{Management implication and conclusions}

Green areas within the city have become increasingly important places for conserving biodiversity. They can also be designed with the goal of attracting specific pollinators, such as bees (Owen 1991; Tommasi et al. 2004; McFrederick and Le Buhn 2006; Tait 2006; Fetridge et al. 2008; Matteson et al. 2008; Wojcik et al. 2008; Kearns and Oliveras 2009; Pawelek et al. 2009; Matteson and Langellotto 2010), and thus can contribute to conservation of local fauna, especially when utilizing native plant species 
(McIntyre and Hostetler 2001; McKinney 2002; Cane et al. 2006). We recommend that the results of our study should be taken into account in landscape planning within urban areas.

Our results also show that, in contrast to some expectations and published literature, the diversity of the bee community can remain relatively stable across an urban gradient. This stability leads to a suggestion that the distinct man-made landscape transformation in the city centre of Poznań also has important advantages for the studied insects and gives them the opportunity to increase in number and ensure existence of a species-rich community. However, we have found that the urbanized landscape can act as a filter for the bee community since some specific ecological traits facilitate colonization of the city centre. As a consequence, city zones across the urbanization gradient differed in term of species composition. Therefore, efforts targeted at bee conservation (e.g. distribution of protected areas) should not be concentrated in one city zone; instead protection across a wide range of habitats of different levels of man-made transformation seems to be the most appropriate strategy for bee diversity conservation in cities.

Acknowledgments We would like to thank Józef Banaszak for help with bee identification and Maciej Łochyński for map preparation. We are deeply grateful to Tim Sparks for improving the English and valuable comments on the manuscript. Anonymous reviewers provided helpful comments on the previous version of the text. We acknowledge the gracious hospitality of all landowners for allowing us to collect data on their property.

Open Access This article is distributed under the terms of the Creative Commons Attribution Noncommercial License which permits any noncommercial use, distribution, and reproduction in any medium, provided the original author(s) and source are credited.

\section{Appendix}

See Table 4.

Table 4 Bee species occurring in Poznań-2006-2008 (from Banaszak-Cibicka 2009)

\begin{tabular}{|c|c|c|c|c|c|}
\hline Species & Abundance & $\%$ of total & Sociality & Pollen specificity & Nest substrate \\
\hline Colletes daviesanus (Smith, 1846) & 19 & 0.7 & S & $\mathrm{O}$ & $\mathrm{S}$ \\
\hline Colletes fodiens (Fourcroy, 1785) & 10 & 0.4 & $S$ & $\mathrm{O}$ & $\mathrm{S}$ \\
\hline Hylaeus angustatus (Schenck, 1859) & 15 & 0.6 & S & $\mathrm{P}$ & $\mathrm{C}$ \\
\hline Hylaeus bisinuatus (Förster, 1871) & 5 & 0.2 & $S$ & $\mathrm{P}$ & $\mathrm{C}$ \\
\hline Hylaeus communis (Nylander, 1852) & 18 & 0.7 & $S$ & $\mathrm{P}$ & $\mathrm{C}$ \\
\hline Hylaeus confusus (Nylander, 1852) & 1 & 0.1 & S & $\mathrm{P}$ & $\mathrm{C}$ \\
\hline Hylaeus gibbus (Saunders, 1850) & 4 & 0.1 & $S$ & $\mathrm{P}$ & $\mathrm{C}$ \\
\hline Hylaeus gracilicornis (Morawitz, 1867) & 1 & 0.1 & $S$ & $\mathrm{P}$ & $\mathrm{C}$ \\
\hline Hylaeus hyalinatus (Smith, 1842) & 59 & 2.3 & $S$ & $\mathrm{P}$ & $\mathrm{C}$ \\
\hline Hylaeus punctatus (Brulle, 1832) & 1 & 0.1 & $\mathrm{~S}$ & $\mathrm{P}$ & $\mathrm{C}$ \\
\hline Hylaeus signatus (Panzer, 1798) & 2 & 0.1 & $S$ & $\mathrm{P}$ & $\mathrm{C}$ \\
\hline Andrena barbilabris (Kirby 1802) & 6 & 0.2 & $\mathrm{~S}$ & $\mathrm{P}$ & $\mathrm{S}$ \\
\hline Andrena bicolor (Fabricius, 1775) & 11 & 0.4 & $\mathrm{~S}$ & $\mathrm{P}$ & $\mathrm{S}$ \\
\hline Andrena bimaculata (Kirby 1802) & 4 & 0.1 & $\mathrm{~S}$ & $\mathrm{P}$ & $\mathrm{S}$ \\
\hline Andrena cineraria (Linnaeus, 1758) & 1 & 0.1 & $\mathrm{~S}$ & $\mathrm{P}$ & $\mathrm{S}$ \\
\hline Andrena dorsata (Kirby 1802) & 18 & 0.7 & $\mathrm{~S}$ & $\mathrm{P}$ & $\mathrm{S}$ \\
\hline Andrena flavipes (Panzer, 1799) & 49 & 1.9 & $\mathrm{~S}$ & $\mathrm{P}$ & $\mathrm{S}$ \\
\hline Andrena florea (Fabricius, 1793) & 2 & 0.1 & $\mathrm{~S}$ & $\mathrm{O}$ & $\mathrm{S}$ \\
\hline Andrena fulva (Müller, 1766) & 73 & 2.9 & S & $\mathrm{P}$ & $\mathrm{S}$ \\
\hline Andrena gravida (Imhoff, 1899) & 14 & 0.5 & $\mathrm{~S}$ & $\mathrm{P}$ & $\mathrm{S}$ \\
\hline Andrena haemorrhoa (Fabricius, 1781) & 277 & 11.1 & S & $\mathrm{P}$ & $\mathrm{S}$ \\
\hline Andrena helvola (Linnaeus, 1758) & 30 & 1.2 & $\mathrm{~S}$ & $\mathrm{P}$ & $\mathrm{S}$ \\
\hline Andrena jacobi (Perkins, 1921) & 4 & 0.1 & $\mathrm{~S}$ & $\mathrm{P}$ & $\mathrm{S}$ \\
\hline Andrena labiata (Fabricius, 1781) & 4 & 0.1 & $\mathrm{~S}$ & $\mathrm{P}$ & $\mathrm{S}$ \\
\hline Andrena minutula (Kirby, 1802) & 4 & 0.1 & $\mathrm{~S}$ & $\mathrm{P}$ & $\mathrm{S}$ \\
\hline Andrena minutuloides (Perkins, 1914) & 12 & 0.4 & $\mathrm{~S}$ & $\mathrm{P}$ & $\mathrm{S}$ \\
\hline Andrena mitis (Schmiedeknecht, 1838) & 1 & 0.1 & $\mathrm{~S}$ & $\mathrm{P}$ & $\mathrm{S}$ \\
\hline Andrena nigroaenea (Kirby, 1802) & 5 & 0.2 & $\mathrm{~S}$ & $\mathrm{P}$ & $\mathrm{S}$ \\
\hline
\end{tabular}


Table 4 continued

\begin{tabular}{|c|c|c|c|c|c|}
\hline Species & Abundance & $\%$ of total & Sociality & Pollen specificity & Nest substrate \\
\hline Andrena nitida (Müller, 1776) & 137 & 5.5 & $S$ & $\mathrm{P}$ & $S$ \\
\hline Andrena ovatula (Kirby, 1802) & 1 & 0.1 & $\mathrm{~S}$ & $\mathrm{O}$ & $S$ \\
\hline Andrena praecox (Scopoli, 1763) & 11 & 0.4 & S & $\mathrm{P}$ & S \\
\hline Andrena subopaca (Nylander, 1848) & 15 & 0.6 & S & $\mathrm{P}$ & S \\
\hline Andrena tibialis (Kirby, 1802) & 10 & 0.4 & S & $\mathrm{P}$ & S \\
\hline Andrena vaga (Panzer, 1799) & 164 & 6.5 & $S$ & $\mathrm{O}$ & S \\
\hline Andrena varians (Rossi, 1792) & 1 & 0.1 & $S$ & $\mathrm{P}$ & S \\
\hline Andrena ventralis (Imhoff, 1832) & 87 & 3.4 & $S$ & $\mathrm{P}$ & S \\
\hline Andrena wilkella (Kirby, 1802) & 2 & 0.1 & $S$ & $\mathrm{O}$ & $S$ \\
\hline Panurgus calcaratus (Scopoli, 1763) & 7 & 0.2 & S & $\mathrm{O}$ & S \\
\hline Halictus quadricinctus (Fabricius, 1776) & 2 & 0.1 & $S$ & $\mathrm{P}$ & $S$ \\
\hline Halictus rubicundus (Christ, 1791) & 5 & 0.2 & $\mathrm{E}$ & $\mathrm{P}$ & $S$ \\
\hline Halictus sexcinctus (Fabricius, 1775) & 9 & 0.3 & $\mathrm{~S}$ & $\mathrm{P}$ & S \\
\hline Seladonia confusa (Smith, 1853) & 2 & 0.1 & $\mathrm{E}$ & $\mathrm{P}$ & $S$ \\
\hline Seladonia leucahenea (Ebmer, 1972) & 1 & 0.1 & $\mathrm{E}$ & $\mathrm{P}$ & $S$ \\
\hline Seladonia subaurata (Rossi, 1792) & 11 & 0.4 & $\mathrm{E}$ & $\mathrm{P}$ & $S$ \\
\hline Seladonia tumulorum (Linnnaeus, 1758) & 37 & 1.4 & $\mathrm{E}$ & $\mathrm{P}$ & $S$ \\
\hline Lasioglossum sexnotatum (Kirby, 1802) & 22 & 0.8 & $\mathrm{~S}$ & $\mathrm{P}$ & $S$ \\
\hline Evylaeus albipes (Fabricius, 1781) & 27 & 1.0 & $\mathrm{E}$ & $\mathrm{P}$ & $S$ \\
\hline Evylaeus brevicornis (Schenck, 1863) & 9 & 0.3 & $\mathrm{E}$ & $\mathrm{P}$ & $S$ \\
\hline Evylaeus calceatus (Scopoli, 1763) & 62 & 2.4 & $\mathrm{E}$ & $\mathrm{P}$ & $S$ \\
\hline Evylaeus laticeps (Schenck, 1868) & 66 & 2.6 & $\mathrm{E}$ & $\mathrm{P}$ & $S$ \\
\hline Evylaeus linearis (Schenck, 1869) & 20 & 0.8 & $\mathrm{E}$ & $\mathrm{P}$ & $S$ \\
\hline Evylaeus lucidulus (Schenck, 1861) & 3 & 0.1 & $\mathrm{~S}$ & $\mathrm{P}$ & $S$ \\
\hline Evylaeus morio (Fabricius, 1793) & 38 & 1.5 & $\mathrm{E}$ & $\mathrm{P}$ & $S$ \\
\hline Evylaeus nitidulus (Fabricius, 1804) & 51 & 2.0 & $\mathrm{E}$ & $P$ & $S$ \\
\hline Evylaeus parvulus (Schenck, 1853) & 1 & 0.1 & $\mathrm{~S}$ & $\mathrm{P}$ & $S$ \\
\hline Evylaeus pauxillus (Schenck, 1853) & 63 & 2.5 & $\mathrm{E}$ & $\mathrm{P}$ & $S$ \\
\hline Evylaeus sexstrigatus (Schenck, 1868) & 3 & 0.1 & $S$ & $P$ & $S$ \\
\hline Evylaeus villosulus (Kirby, 1802) & 7 & 0.2 & $\mathrm{~S}$ & $\mathrm{P}$ & $S$ \\
\hline Sphecodes longulus (Hagens, 1882) & 1 & 0.1 & $\mathrm{CP}$ & {$[\mathrm{P}]$} & {$[\mathrm{S}]$} \\
\hline Sphecodes monilicornis (Kirby, 1802) & 2 & 0.1 & $\mathrm{CP}$ & {$[\mathrm{P}]$} & {$[\mathrm{S}]$} \\
\hline Sphecodes puncticeps (Thomson, 1870) & 2 & 0.1 & $\mathrm{CP}$ & {$[\mathrm{P}]$} & {$[\mathrm{S}]$} \\
\hline Dasypoda hirtipes (Harris, 1780) & 37 & 1.4 & $\mathrm{~S}$ & $\mathrm{O}$ & $S$ \\
\hline Anthidium manicatum (Fabricius, 1775) & 11 & 0.4 & $\mathrm{~S}$ & $\mathrm{P}$ & - \\
\hline Stelis punctulatissima (Kirby, 1802) & 3 & 0.1 & $\mathrm{CP}$ & {$[\mathrm{P}]$} & {$[\mathrm{C}]$} \\
\hline Heriades truncorum (Linnaeus, 1758) & 9 & 0.3 & $\mathrm{~S}$ & $\mathrm{O}$ & $\mathrm{C}$ \\
\hline Chelostoma rapunculi (Lepeletier, 1841) & 2 & 0.1 & $S$ & $\mathrm{O}$ & $\mathrm{C}$ \\
\hline Hoplitis adunca (Panzer, 1798) & 1 & 0.1 & $\mathrm{~S}$ & $\mathrm{O}$ & $\mathrm{C}$ \\
\hline Hoplitis leucomelena (Kirby, 1802) & 1 & 0.1 & $\mathrm{~S}$ & $\mathrm{P}$ & $\mathrm{C}$ \\
\hline Osmia aurulenta (Panzer, 1799) & 4 & 0.1 & $\mathrm{~S}$ & $\mathrm{P}$ & $\mathrm{C}$ \\
\hline Osmia coerulescens (Linnaeus, 1758) & 8 & 0.3 & $S$ & $\mathrm{P}$ & $\mathrm{C}$ \\
\hline Osmia mustelina (Gerstaecker, 1869) & 1 & 0.1 & $\mathrm{~S}$ & $\mathrm{O}$ & $\mathrm{C}$ \\
\hline Osmia rufa (Linnaeus, 1758) & 72 & 2.8 & $\mathrm{~S}$ & $\mathrm{P}$ & $\mathrm{C}$ \\
\hline Chalicodoma ericetorum (Lepeletier, 1841) & 1 & 0.1 & $S$ & $\mathrm{O}$ & $\mathrm{C}$ \\
\hline Megachile circumcincta (Kirby, 1802) & 9 & 0.3 & $\mathrm{~S}$ & $\mathrm{O}$ & $\mathrm{S}$ \\
\hline Megachile leachella (Curtis, 1828) & 1 & 0.1 & $\mathrm{~S}$ & $\mathrm{P}$ & - \\
\hline Megachile ligniseca (Kirby, 1802) & 5 & 0.2 & $S$ & $\mathrm{P}$ & $S$ \\
\hline
\end{tabular}


Table 4 continued

\begin{tabular}{|c|c|c|c|c|c|}
\hline Species & Abundance & $\%$ of total & Sociality & Pollen specificity & Nest substrate \\
\hline Megachile pilidens (Alfken, 1923) & 5 & 0.2 & $\mathrm{~S}$ & $\mathrm{P}$ & $\mathrm{S}$ \\
\hline Megachile rotundata (Fabricius, 1784) & 5 & 0.2 & $\mathrm{~S}$ & $\mathrm{P}$ & $\mathrm{C}$ \\
\hline Megachile versicolor (Smith, 1844) & 1 & 0.1 & $\mathrm{~S}$ & $\mathrm{P}$ & $\mathrm{C}$ \\
\hline Megachile willughbiella (Kirby, 1802) & 15 & 0.6 & $\mathrm{~S}$ & $\mathrm{P}$ & $\mathrm{C}$ \\
\hline Coelioxys elongata (Lepeletier, 1841) & 1 & 0.1 & $\mathrm{CP}$ & {$[\mathrm{P}]$} & $\mathrm{S}$ \\
\hline Coelioxys rufocaudata (Smith, 1854) & 1 & 0.1 & $\mathrm{CP}$ & {$[\mathrm{P}]$} & $\mathrm{S}$ \\
\hline Anthophora bimaculata (Panzer, 1798) & 1 & 0.1 & $\mathrm{~S}$ & $\mathrm{P}$ & $\mathrm{S}$ \\
\hline Anthophora furcata (Panzer, 1798) & 1 & 0.1 & $\mathrm{~S}$ & $\mathrm{O}$ & $\mathrm{S}$ \\
\hline Anthophora plumipes (Pallas, 1772) & 64 & 2.5 & $\mathrm{~S}$ & $\mathrm{P}$ & $\mathrm{S}$ \\
\hline Anthophora quadrimaculata (Panzer, 1806) & 8 & 0.3 & $\mathrm{~S}$ & $\mathrm{P}$ & $\mathrm{S}$ \\
\hline Melecta punctata (Fabricius, 1775) & 2 & 0.1 & $\mathrm{CP}$ & {$[\mathrm{P}]$} & {$[\mathrm{S}]$} \\
\hline Nomada fucata (Panzer, 1798) & 2 & 0.1 & $\mathrm{CP}$ & {$[\mathrm{P}]$} & {$[\mathrm{S}]$} \\
\hline Nomada moeschleri (Alfken, 1913) & 1 & 0.1 & $\mathrm{CP}$ & {$[\mathrm{P}]$} & - \\
\hline Nomada panzeri (Lepeletier, 1841) & 1 & 0.1 & $\mathrm{CP}$ & {$[\mathrm{P}]$} & {$[\mathrm{S}]$} \\
\hline Nomada signata (Jurine, 1807) & 3 & 0.1 & $\mathrm{CP}$ & {$[\mathrm{P}]$} & {$[\mathrm{S}]$} \\
\hline Ceratina cyanea (Kirby, 1802) & 4 & 0.1 & $\mathrm{~S}$ & $\mathrm{P}$ & $\mathrm{C}$ \\
\hline Bombus bohemicus (Seidl, 1838) & 2 & 0.1 & $\mathrm{CP}$ & {$[\mathrm{P}]$} & {$[\mathrm{H}]$} \\
\hline Bombus hortorum (Linnaeus, 1761) & 21 & 0.8 & $\mathrm{E}$ & $\mathrm{P}$ & $\mathrm{H}$ \\
\hline Bombus hypnorum (Linnaeus, 1758) & 59 & 2.3 & $\mathrm{E}$ & $\mathrm{P}$ & $\mathrm{H}$ \\
\hline Bombus lapidarius (Linnaeus, 1758) & 73 & 2.9 & $\mathrm{E}$ & $\mathrm{P}$ & $\mathrm{H}$ \\
\hline Bombus lucorum (Linnaeus, 1761) & 60 & 2.4 & $\mathrm{E}$ & $\mathrm{P}$ & $\mathrm{H}$ \\
\hline Bombus pascuorum (Scopoli, 1763) & 165 & 6.6 & $\mathrm{E}$ & $\mathrm{P}$ & $\mathrm{H}$ \\
\hline Bombus pratorum (Linnaeus, 1761) & 19 & 0.7 & $\mathrm{E}$ & $\mathrm{P}$ & $\mathrm{H}$ \\
\hline Bombus ruderarius (Muller, 1776) & 10 & 0.4 & $\mathrm{E}$ & $\mathrm{P}$ & $\mathrm{H}$ \\
\hline Bombus sylvarum (Linnaeus, 1761) & 9 & 0.3 & $\mathrm{E}$ & $\mathrm{P}$ & $\mathrm{H}$ \\
\hline Bombus sylvestris (Lepeletier, 1832) & 2 & 0.1 & $\mathrm{CP}$ & {$[\mathrm{P}]$} & {$[\mathrm{H}]$} \\
\hline Bombus terrestris (Linnaeus, 1758) & 130 & 5.2 & $\mathrm{E}$ & $\mathrm{P}$ & $\mathrm{H}$ \\
\hline Apis mellifera (Linnaeus, 1758) & 136 & 5.4 & $\mathrm{E}$ & $\mathrm{P}$ & $\mathrm{H}$ \\
\hline
\end{tabular}

Abundance total number of specimens collected across all sites and all years. \% of total percentage of total collection $(n=2,495)$ identified as this species. Sociality classification as either E-eusocial, CP-cleptoparasitic, S-solitary. Pollen specificity classification as either polylectic (collecting pollen from multiple plant families) or oligolectic (collecting pollen from a single plant family or genus); [P] indicates parasitic species that do not collect pollen. Nest substrate classification of the nest substrate of each nonparasitic species as C-cavity, H-hive, S-soil; letters in brackets ([]) indicate the nest substrate of the host of a parasitic species; dashes (-) indicate attribute is unknown. The list of species was arranged in systematic order

\section{References}

Ahrné K (2008) Local management and landscape effects on diversity of bees, wasp and birds in urban green areas. $\mathrm{PhD}$ dissertation, Swedish University of Agricultural Sciences

Ahrné K, Bengtsson J, Elmqvist T (2009) Bumble Bees (Bombus spp) along a Gradient of Increasing Urbanization. PLoS ONE 4(5):e5574

Antonini Y, Martins RP (2003) The flowering-visiting bees at the ecological station of the Universidade Federal de Minas Gerais, Belo Horizonte, MG, Brazil. Neotrop Entomol 32(4):565-575

Banaszak J (1973) Pszczołowate (Apoidea) okolic Poznania. Bad Fizjogr Pol Zach B - biologia 26:33-78

Banaszak J (1976) Pszczoły (Hymenoptera: Apoidea) Ogrodu Botanicznego w Poznaniu. Bad Fizjogr Pol Zach C - zoologia 29:71-85

Banaszak J (1982) Bee fauna (Apoidea, Hymenoptera) of Wielkopolska-Kujawy Lowland, Poland. Fragm Faun 27(7):75-92
Banaszak J (1993) Trzmiele Polski. Wyd. Uczelniane WSP w Bydgoszczy, Bydgoszcz, p 158

Banaszak J (2004) Investigations on wild bees in the city of Bydgoszcz, North Poland (Hymenoptera, Apoidea). In: Indykiewicz P, Barczak T (eds) Fauna miast Europy Środkowej 21. wieku. Wyd. LOGO, Bydgoszcz, pp 225-233

Banaszak J, Czechowski W, Pisarski B, Skibińska E (1978) Owady społeczne w środowisku zurbanizowanym. Kosmos Seria A-Biologia 2(251):173-180

Banaszak J, Romasenko L, Cierzniak T (2001) Klucze do oznaczania owadów Polski. Cz. XXIV Błonkówki-Hymenoptera. Zeszyt 68f-Podrodzina Megachilinae. Polskie Tow Entomol, Toruń

Banaszak-Cibicka W (2009) Specificity of city bee fauna (Hymenoptera: Apoidea: Apiformes) on the example of Poznań, Poland. PhD dissertation, Adam Mickiewicz University, Poznań

Bańkowska R (1980) Fly communities of the family Syrphidae in natural and anthropogenic habitats of Poland. Memorab Zool 33:3-93 
Bańkowska R (1981) Hover flies (Diptera, Syrphidae) of Warsaw and Mazovia. Memorab Zool 35:57-78

Cane JH (2005a) Bees, pollination, and the challenges of sprawl. In: Johnson EA, Klemens MW (eds) Nature in fragments: the legacy of sprawl. Columbia University Press, New York, pp 109-124

Cane JH (2005b) Pollination potential of the bee Osmia aglaia for cultivated red raspberries and blackberries (Rubus: Rosaceae). Hort Sci 40:1705-1708

Cane JH, Minckley RL, Kervin L, Roulston TH, Williams N (2006) Complex responses within a desert bee guild (Hymenoptera: Apiformes) to urban habitat fragmentation. Ecol Appl 16:632-644

Chao A, Li PC, Agatha S, Foissner W (2006) A statistical approach to estimate soil ciliate diversity and distribution based on data from five continents. Oikos 114:479-493

Chapman RE, Bourke AFG (2001) The influence of sociality on the conservation biology of social insects. Ecol Lett 4:650-662

Cierzniak T (2003) Ekologia pszczół w dynamicznym kręgu zbiorowisk grądowych. Wydawnictwo Akademii Bydgoskiej im. Kazimierza Wielkiego, Bydgoszcz, p 158

Clucas B, McHugh K, Caro T (2008) Flagship species on covers of US conservation and nature magazines. Biodivers Conserv $17: 1517-1528$

Colwell RK (2005) EstimateS: statistical estimation of species richness and shared species from samples. Version 8.0.0. http://purl.oclc.org/estimates

Eremeeva NI, Sushchev DV (2005) Structural changes in the fauna of pollinating insects in urban landscapes. Russ J Ecol 36(4): 259-265

Fetridge ED, Ascher JS, Langellotto GA (2008) The bee fauna of residential gardens in a suburb of New York City (Hymenoptera: Apoidea). Ann Entomol Soc Am 101(6):1067-1077

Frankie G, Thorp RW, Schindler M, Hernandez J, Ertter B, Rizzardi M (2005) Ecological patterns of bees and their host ornamental flowers in two northern California cities. J Kans Entomol Soc 78:227-246

Gascon C, Lovejoy T, Bierregaard OJ, Malcolm JR, Stouffer P, Vasconcelos H, Laurance W, Zimmerman B, Tocher M, Borges S (1999) Matrix habitat and species richness in tropical forest remnants. Biol Conserv 91:223-229

Gaston K, Smith R, Thompson K, Warren P (2005) Urban domestic gardens (II): experimental tests of methods for increasing biodiversity. Biodivers Conserv 14:395-413

Gotelli NJ, Colwell RK (2001) Quantifying biodiversity: procedures and pitfalls in the measurement and comparison of species richness. Ecol Lett 4:379-391

Goulson D, Hughes WHO, Derwent LC, Stout JC (2002) Colony growth of the bumblebee, Bombus terrestris, in improved and conventional agricultural and suburban habitats. Oecologia 130: 267-273

Grimm NB, Faeth SH, Golubiewski NE, Redman CL, Wu J, Bai X, Briggs JM (2008) Global change and the ecology of cities. Science 319:756-760

Hernandez JL, Frankie GW, Thorp RW (2009) Ecology of urban bees: a review of current knowledge and directions for future study. Cities Environ 2(1):15 Article 3

Hinners SJ (2008) Pollinators in an urbanizing landscape: effects of suburban sprawl on a grassland bee assemblage. PhD Dissertation, University of Colorado

Home R, Keller C, Nagel P, Bauer N, Hunziker M (2009) Selection criteria for flagship species by conservation organizations. Environ Conserv 36:139-148

Johnson JB, Omland KS (2004) Model selection in ecology and evolution. Trends Ecol Evol 19:101-108

Kadlec T, Kotela MAAM, Novák I, Konvička M, Jarošik V (2009) Effect of land use and climate on the diversity of moth gilds with different habitat specialization. Community Ecol 10(2):152-158
Kearns CA, Oliveras DM (2009) Environmental factors affecting bee diversity in urban and remote grassland plots in Boulder, Colorado. J Insect Conserv 13:655-665

Kozlov M (1996) Patterns of forest insect distribution within a large city: Lepidoptera in St. Petersburg, Russia. J Biogeogr 23: 95-103

Lepš J, Šmilauer P (2003) Multivariate Analysis of Ecological Data using CANOCO. Cambridge University Press, Cambridge

Loram A, Tratalos J, Warren P, Gaston K (2007) Urban domestic gardens $(\mathrm{X})$ : the extent and structure of the resource in five major cities. Landscape Ecol 22:601-615

Matteson KC, Langellotto GA (2009) Bumble bee abundance in New York City community gardens: implications for urban agriculture. Cities Environ 2:12 Article 5

Matteson KC, Langellotto GA (2010) Determinates of inner city butterfly and bee species richness. Urban Ecosyst 13:333-347

Matteson KC, Ascher JS, Langellotto GA (2008) Bee richness and Abundance in New York City Urban Gardens. Ann Entomol Soc Am 101(1):140-150

McFrederick QS, Le Buhn G (2006) Are urban parks refuges for bumble bees Bombus spp. (Hymenoptera: Apoidea)? Biol Conserv 129:372-382

McIntyre NE, Hostetler ME (2001) Effects of urban land use on pollinator (Hymenoptera: Apoidea) communities in a desert metropolis. Basic Appl Ecol 2:209-218

McIntyre NE, Ranjo J, Fagan WF, Faeth SH (2001) Ground arthropod community structure in a heterogeneous urban environment. Landsc Urban Plan 52:257-274

McKinney ML (2002) Urbanization, biodiversity, and conservation. Bioscience 52(10):883-890

McKinney ML (2006) Urbanization as a major cause of biotic homogenization. Biol Conserv 109:37-45

McKinney ML (2008) Effects of urbanization on species richness: A review of plants and animals. Urban Ecosyst 11:161-176

Mulder MB, Schacht R, Caro T, Schacht J, Caro B (2009) Knowledge and attitudes of children of the Rupununi: implications for conservation in Guyana. Biol Conserv 142:879-887

Niemelä J, Kotze J, Ashworth A (2000) The search for common anthropogenic impacts on biodiversity: a global network. J Insect Conserv 4:3-9

Owen J (1991) The ecology of a Garden: the first fifteen years. Cambridge University Press, Cambridge, p 403

Pawelek JC, Frankie GW, Thorp RW, Przybylski M (2009) Modification of a community garden to attract native bee pollinators in urban San Luis Obispo, California. Cities Environ 2(1): $1-20$

Pawlikowski T, Celary W (2003) Klucze do oznaczania owadów Polski. Cz. XXIV Błonkówki-Hymenoptera. Zeszyt 68a. Pszczołowate-Apidae. Wstęp i podrodzina lepiarkowateColletidae. Polskie Tow Entomol, Toruń

Pesenko YA, Banaszak J, Cierniak T (2002) Klucze do oznaczania owadów Polski, Cz. XXIV Błonkówki-Hymenoptera. Zeszyt 68b. Podrodzina smuklikowate-Halictinae. Polskie Tow Entomol, Toruń

Quinn GP, Keough MJ (2002) Experimental design and data analysis for biologists. Cambridge Univ Press, Cambridge

Sattler T, Borcard D, Arlettaz R, Bontdina F, Legendre P, Obrist MK, Moretti M (2010) Spider, bee, and bird communities in cities are shaped by environmental control and high stochasticity. Ecology 91(11):3343-3353

Scheuchl E (1995) Illustrierte Bestimmungstabellen der Wildbinen Deutschlands und Österreichs 1: Anthophoridae. Eigenverlag, Velden, p 158

Schmid-Egger C, Scheuchl E (1997) Illustrierte Bestimmungstabellen der Wildbinen Deutschlands und Österreichs 3: Andrenidae. Eigenverlag, Velden, p 180 
Stelzer RJ, Chittka L, Carlton M, Ings TC (2010) Winter active bumblebees (Bombus terrestris) achieve high foraging rates in urban Britain. PLoS ONE 5(3):e9559. doi:10.1371/journal. pone.0009559

Tait M (2006) Wildlife gardening for everyone. Think Publishing, London, p 288

Thompson K, Austin KC, Smith RM, Warren PH, Angold PG, Gaston KJ (2003) Urban domestic gardens (I): putting small-scale plant diversity in context. J Veg Sci 14:71-78

Tommasi D, Miro A, Higo HA, Winston ML (2004) Bee diversity and abundance in an urban setting. Can Entomol 136:851-869

Van Dyck H, Matthysen E (1999) Habitat fragmentation and insect flight; a changing 'design' in a changing landscape? Trends Ecol Evol 14:172-174

Winfree R, Griswold T, Kremen C (2007) Effect of human disturbance on bee communities in a forested ecosystem. Conserv Biol 21(1):213-223

Wojcik VA, Frankie GW, Thorp RW, Hernandez JL (2008) Seasonality in bees and their flora resource plants at constructed urban bee habitat in Berkeley, California. J Kansas Entomol Soc 81(1):15-28

Wójtowski F, Szymaś B (1973a) Dziko żyjące pszczołowate (Hym. Apoidea) terenów zieleni miejskiej Poznania. Roczniki Akad Roln w Poznaniu 66:163-169

Wójtowski F, Szymaś B (1973b) Entomofauna pasożytnicza i towarzysząca pszczołom samotniczym (Apidae solitariae) w pułapkach gniazdowych. Roczniki Akad Roln w Poznaniu 66:171-179

Wójtowski F, Feliszek H (1977) Apidofauna zapylająca drzewa i krzewy owocowe w pracowniczych ogródkach działkowych Poznania. Roczniki Akad Roln w Poznaniu 94:235-241

Zanette LRS, Martins RP, Ribeiro SP (2005) Effects of urbanization on Neotropical wasp and bee assemblages in Brazilian metropolis. Landsc Urban Plan 71:105-121

Zerbe S, Maurer U, Schmitz S, Sukopp H (2003) Biodiversity in Berlin and its potential for nature conservation. Landsc Urban Plan 62:139-148 